\title{
Efficiency Measurement of Cardamom Farms in the Hilly Region of Nepal: A Non-parametric Approach
}

\author{
Bhima Dhungana, Yasuhiro Sugimoto*, Naoyuki Yamamoto \\ and Hideyuki KANO
}

\begin{abstract}
The purpose of this research was to estimate the economic, allocative, technical, pure technical and scale efficiencies of rural cardamom farms in the hilly region of Nepal. Data Envelopment Analysis (DEA) was used to estimate the efficiency scores. Additionally, Tobit regression was also used to explain the variation in the efficiency scores related to farm-specific factors. The efficiency scores of 100 surveyed cardamom farms revealed that the economic, allocative, technical, pure technical and scale efficiencies were an average of 52, 58, 90, 95 and 96 percent, respectively. The results indicate there can be substantial reduction in inputs and the same level of output can be achieved with the existing technology. In addition, the Tobit regression analysis showed a positive significant effect on efficiencies attributed to farm-specific variables, such as cropping year, credit use, women participation, training and off-farm income. To enhance the efficiencies of rural cardamom farms in the hilly region of Nepal, major policy implications should include adequate government arrangements of credit, training programs, encouragement of women participants, and increasing off-farm income sources.
\end{abstract}

JEL Classification: Q12

Keywords : Cardamom Farming, Efficiency Measurement, Hilly Region of Nepal, Non-parametric Approach

\section{Introduction}

Nepal is divided into three main ecological zones: the Terai (plains), the Hills and the Himalayas. Agriculture is the main sector of the national economy ; contributing $36 \%$ of gross domestic product (GDP) and accounting for 76\% of employment in 2007 (see Ministry of Agriculture \& Cooperatives [27]). Horticulture contributed 21\% to agricultural GDP, and fruits and spices shared a 7.04\% contribution (see Central Bureau of Statistics, [11]). However, Nepalese agriculture can still only be characterized as a subsistence and cerealbased mixed farming system.

Against the context of conventional agricultural practices, the Agricultural Prospective Plans (see APP, [2]) has placed high priority on the production and commercialization as high-value crops, such as large cardamom (Amomum subulatum Roxb.), citrus and vegeta-

* Faculty of Agriculture, Department of Environment and Resource Sciences, Interdisciplinary Graduate School for Agriculture and Engineering, University of Miyazaki 1-1, Gakuen Kibanadai-Nishi Miyazaki, 889-2192 Japan, Tel. Fax : +81-985-58-7253

Email address : y.sugimo@cc.miyazaki-u.ac.jp

Received: 1st October 2009 Accepted: 25th April 2010

(C) 日本地域学会 (JSRSAI) 2010 
bles. The present research was concerned with large cardamom cultivation in Nepal. Although it is not well developed, its history goes back more than 200 years when the crop was grown for medicinal purposes. After 1964, cardamom was established as a high-value herbaceous perennial crop, cultivated over 12,000 hectares and 40 Districts, mainly in the mid-hill region (600 to 2,000 meters with an annual rainfall of 1,500 to 2,500 mm). Shadowy, moist and sloping land is most suitable for the crop. Land where it can be planted is less suitable for other crops, but it can be a part of a small-scale agro-forestry system (0.05-0.17 hectares per family), intercropped for nitrogen fixation (see Zomer \& Menke [40]). This may also help to prevent the environmental degradation occurring in the hills due to the clearing of land for cereal cropping.

The varieties of large cardamom are found in Nepal, Ramsey, Dambersey, Sawney, Golsey, Chibesey and Ramla, with Ramsey, Golsey and Chibesey being the most widely distributed (see Agro Enterprise Centre [3]). Economic yields start from three years after planting, with the optimal yield period at 8 to 10 years during the 20 to 25 year lifespan of the tree. The harvested fruits are processed mainly by the traditional smoking method (locally known as the traditional bhatti system) or using improved drying technologies. Fuel consumption is in the range of 1 to $2.5 \mathrm{~kg}$ fuel wood per $\mathrm{kg}$ fresh cardamom (see Rao, et al. [31]) using the bhatti system. Almost all of the production is exported, with nearly $90 \%$ to India.

The popularity of production of this crop has significantly increased over the last three decades. Nepal became the global leader (51\%) in the production and export of large cardamom, surpassing India and Bhutan. Approximately 13,237 hectares are under cardamom cultivation out of a total of 3.09 million hectares of agricultural land, with an estimated annual production of 6,792 metric tons and $0.5 \mathrm{Mt} /$ ha yield as of 2007 . Ilam, the District that first began producing large cardamom, occupies the position of third largest in cardamom production area (21\%), second largest in yield (21\%) and largest in overall spice production in the country (see Ministry of Agriculture \& Cooperatives [27]).

Cardamom farming in Nepal is still carried out under traditional farming systems, due to a lack of modern facilities, farmer education, developed infrastructure, appropriate communication, access to credit, and research and development. Owing to these limitations, there are considerable difficulties in developing understanding and adopting new technologies (see Bozoğlu \& Ceyhan [9]). The aim is to use minimal farm inputs while continuing to improve the final output, so that the efficiency of the production system will impart a profit to the farmer in a sustainable manner. In the short-term, it is important to identify the bestperforming farms given the available inputs and the existing technology.

Through first step analysis, several researchers from various countries have identified substantial inefficiencies and potential policies to improve productivity of farms. Many empirical studies have measured the farm-level efficiency in developing countries by using the Data Envelopment Analysis (DEA) for various crops, including rice production in Bangladesh (see Wadud [38]) and Gambia (see Chavas, et al. [12]), coffee in Vietnam (see Rios \& Shively [32]), vegetables in Turkey (see Bozoğlu \& Ceyhan [9]) and citrus in Spain (see Picazo-Tadeo \& Reig-Martinez [30]). The literature indicated that farm-level efficiency and productivity were not as satisfactory as expected in these studies; however, not 
enough research has been conducted in Nepal in this sector. In our best knowledge, the technical efficiency of rice farms (see Dhungana, et al. [18], Belbase \& Grabowski [7], Kebede [26]) and citrus farms (see Dhungana, et al. [17]) only were found evaluated in Nepal. In the case of cardamom, there is hardly few research work done on production sector, however, its energy efficiency (see Sharma, et al. [34]) and nitrogen-fixing benefits (see Sharma \& Ambasht [33]) in forestry in Sikkim of India were evaluated. The limited studies available have not specifically focused on factors affecting farm-level technical efficiency or efficiency measurement in cardamom production. These facts obviously reflect the novelty and originality of the work in the field that inspired us to explore the reason that possibly hinder the productivity growth in cardamom farm.

In the second step, we used Tobit model to analyze the determinants of efficiency as suggested by Speelman, et al. [34]. This model was used for estimation of various factors among the human and structural variables (see Chavas, et al. [14]) to identify the most important factor that may attribute for improving the efficiency of the farm.

Hence, the objectives of this study are to measure the efficiency of selected cardamom farms in Nepal and to explore the determinants of efficiency. To achieve this objective, a two-step methodology was employed, involving the DEA approach which measure the farmlevel technical efficiency (TE), economic efficiency (EE) and allocative efficiency (AE), and the Tobit model which estimate the role of farm-specific factors in efficiency.

\section{Methods}

\subsection{Study area and data collection}

Nepal is a leading producer of the cardamom in the world, in which, Ilam District is in third position among the 75 Districts. In turn, Santidanda, Pashupatinagar and Fikkal Village Development Committees (VDCs) are highly popular for cardamom production. Hence, the study was carried out in these three local administrative units from the Ilam District as specified in Figure 1. The various factors, such as climate, altitude, ethnicity and proximity to the market of three different villages were observed quite resembling to each others. Hence, a total of 100 farmers from these three locations were interviewed to collect the data via prepared questionnaires during the cropping year, 2007-08. The District is

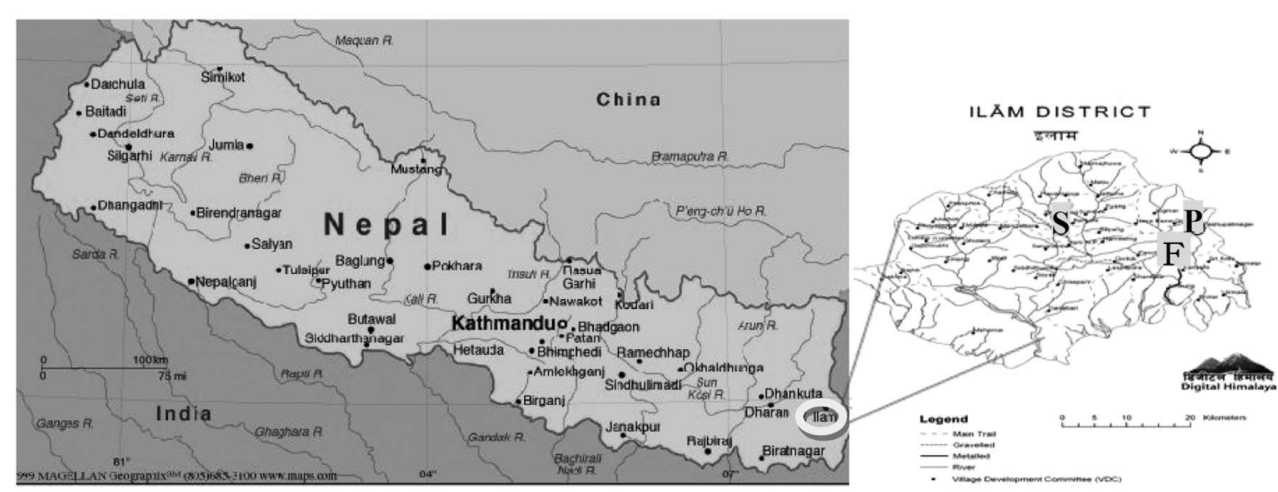

Figure 1. Location of the study area Note: $\mathrm{S}=$ Santidanda, $\mathrm{F}=$ Fikkal and $\mathrm{P}=$ Pashupatinagar, $(\mathrm{VDC})$ 
comprised of forty-seven VDCs, forty of which are accessible by road, but many of these can only be used during the dry months of winter. Agricultural production is highly dependent on the monsoonal rains, which fall between June and September. Only 13\% of the farmland is additionally irrigated. Agriculture is the main occupation (nearly 80\%) of the people and small-scale traditional farming systems dominate the area.

The major food crops grown include maize, rice and millet, while the major high-value crops grown are cardamom, tea and vegetables. The changes that are occurring in this District are in line with government policies of the Eighth and Ninth Plans to diversify and commercialize the agriculture to increase income. The study area was situated within the sub-temperate region, with an elevation of $1,200 \mathrm{~m}$, annual rainfall 2,000 $\mathrm{mm}$ and temperatures from $10^{\circ} \mathrm{C}$ to $20^{\circ} \mathrm{C}$. A large number of smallholder farmers in the Ilam District are pioneers in the farming of cardamom, providing a representative sample of farmers for the study. For the calculation of efficiency, input data was collected on area of land (hectares), labor (days), fertilizers (kg), seeds (sapling) and wood (kg). Output (kg) and the associated costs and all prices were calculated in Nepalese Rupees (Rs).

\subsection{Data analysis}

\subsubsection{Non-parametric DEA approach}

The determination of efficiency is highly preferable to indicate whether a farm uses the best available technology in its production processes (see Chavas \& Cox [13]). TE can be estimated by employing different approaches, including stochastic production frontier (SPF) analysis and DEA, also called the non-parametric approach. These two methods have a range of strengths and weaknesses which may influence the choice of method in a particular application; the constraints, advantages and disadvantages of each approach have been discussed by Coelli and Perelman [16]. Although several studies have compared the SPF and DEA approaches and have found the efficiency score estimates from each approach to differ, the efficiency ranking of farms appears to be quite similar (see Alene [4]; Waded \& White [37] ; Sharma, et al. [34]). These findings suggest that the choice of method depends upon the research objectives, data viability and the nature of the farms.

In the present study, the DEA approach was used to evaluate the relative efficiency of farms with multiple inputs and outputs, as used by Charnes, et al. [12] and Banker, et al. [5]. This model leads to a ranking of all unit observations on the basis of efficiency scores. The focus is not on the estimation of an average technology production function used by all units in the analysis, but rather, to identify the best practicing units. A best-practice production frontier is constructed and all units of analysis are related to this frontier. The main advantage of this method is it requires neither a priori weights nor explicit specification of functional relationships among the multiple outputs and inputs and absence of random shocks in the data set (see Coelli and Perelman [16]). This method is useful for studies in countries like Nepal, as data are more limited and production technologies are not well understood. It also offers target values of inputs and outputs to inefficient units, which can lead to improved efficiency. There are two stages in the analysis of the data: production efficiency estimation and the regression of these measures on several hypothesized socioeconomic and institutional factors affecting efficiency. 
The estimation of farm activity (the decision-making unit) is usually based on EE and AE. TE is defined as the degree to which a farm is able to produce the maximum possible output from a given technology and bundle of inputs, while AE reflects the ability of a farm to use the inputs in optimal proportions, given input prices and production technology. These two efficiency measures are combined to provide a measure of total economic efficiency according to Farrell's [21] definition. TE can be divided into two components : pure TE and scale efficiency (SE). SE relates to the degree of efficiency of the scale of operation, as related to maximizing average productivity.

The five relative efficiency scales are derived using the input-orientated DEA approach. Various authors, such as Charnes, et al. [12], Banker, et al. [5] and Fare, et al. [20] have estimated the values by solving a separate linear equation for each farm in the sample. In the present study, we assumed that farm $i(i=1,2, \cdots 100)$ produces cardamom $\left(y_{i}\right)$ using existing inputs, $x_{i j}$ ( $j=$ inputs of land, labor, seeds, saplings, fertilizer and wood), and $c_{i j}$ represents the input price for $j$ used by farm $i$, where, $x_{i j}{ }^{*}$ is the cost-minimizing vector of input quantities for the $i^{\text {th }}$ farm, given the input prices $c_{i j}$ and $\lambda_{i}$ is an $n \times 1$ vector of constants. DEA Excel solver software as developed by Zhu [39] was used for the analyses.

\subsubsection{Technical efficiency (TE)}

The overall TE proposed by Charnes et al. [12] had an input orientation under constant returns to scale (CRS). The model was presented for $m$ inputs and $s$ outputs for each of the farmers (farms) or each decision-making unit (DMU). For the $i^{\text {th }}$ farm we arranged $x_{i}$ and $y_{i}$ by the column vector inputs and outputs, respectively. The $m \times n$ input matrix, $X$, and $s$ $\times n$ output matrix, $Y$, represent the data for all $N$ cardamom farms. The DEA model to calculate the TE is presented in equation (1):

$$
\begin{array}{cl}
\operatorname{Min}_{\theta, \lambda} \theta, & \\
\text { Subject to } & -y_{i}+Y \lambda \geq 0, \\
& \theta x_{i}-X \lambda \geq 0, \\
& N 1^{\prime} \lambda=1 \\
& \lambda \geq 0,
\end{array}
$$

where $\theta$ is a scalar and $\lambda$ is an $n \times 1$ vector of constants, $N 1$ is an $N \times 1$ vector of ones, $Y \lambda$ and $X \lambda$ are the efficiency projections on the frontier. The value of $\theta$ addresses the score of TE for the $i^{\text {th }}$ farm. This score will always lie between 0 and 1 , where $\theta_{i}=1$ indicates that the farmer is 100 per cent technically efficient or lies on the frontier, according to the definition of Farrell [21]. Thus, $1-\theta_{i}$ shows how much $i^{\text {th }}$ farm's inputs can be proportionally reduced without any loss in output. It should be noted that equation 1 has a variable returns to scale (VRS) specification which includes a convexity constraint $\left(N 1^{\prime} \lambda=1\right)$. Without this convexity constraint, equation (1), would have constant returns to scale specification (CRS). The sample data output variable used was $y_{i}$ (production in $\mathrm{kg}$ ) and inputs variables were: $x_{i 1}=$ land (ha), $x_{i 2}=$ labor (days), $x_{i 3}=$ fertilizers (kg,) $x_{i 4}=$ sapling (seeds) and $x_{i 5}=$ faire wood $(\mathrm{kg})$. These are common production inputs.

\subsubsection{Economic efficiency (EE)}

Economic efficiency is a measure of the degree to which the cost of producing a given output is kept to a minimum. In order to derive overall economic efficiency (EE), we first 
solve the cost minimising DEA model, as specified in equation (2).

$$
\begin{aligned}
\operatorname{Min}_{\lambda, x_{i}^{*} C_{i}{ }^{\prime} x_{i}{ }^{*},} & \\
\text { Subject to } & -y_{i}+Y \lambda \geq 0, \\
& x_{i}{ }^{*}-X \lambda \geq 0, \\
& N 1^{\prime} \lambda=1, \\
& \lambda \geq 0,
\end{aligned}
$$

where, $x_{i j}{ }^{*}$ is the cost-minimising (which is calculated by the model) vector of input quantities for the $i^{\text {th }}$ farm, under the CRS assumption, and $\lambda_{i}$ values are the weights to be used as multipliers for the input levels of the $i^{\text {th }}$ farm, given the input price $c_{i j}$ and the output levels $y_{i}$. The same output variables and the total input cost $c$ were used to solve the economic (cost) efficiency DEA model (equation 2). After denoting the actual cost for observation $i^{\text {th }}$ farm as $c_{i j} \times x_{i j}, E E$ is defined as the ratio of minimum to actual observed costs for the $i^{\text {th }}$ farm : $E E_{i}=\left(c_{i j}, x_{i j}{ }^{*}\right) /\left(c_{i j} \times x_{i j}\right)$. This measure of $E E$ can take values ranging from 0 to 1 , where a value of 1 indicates that the $i^{\text {th }}$ farm is economically efficient.

\subsubsection{Allocative efficiency (AE)}

Allocative efficiency (AE) is represented by the ratio of $\mathrm{EE}$ and $\mathrm{TE}$, as outlined by Farrell [21]. He proposed that AE reflects the ability of a farm to use the inputs in optimal proportions, given their respective prices, based on the constant returns to scale assumption.

$$
A E_{i}\left(y_{i}, x_{i j}, c_{i j}\right)=\left[E E_{i}\left(y_{i}, x_{i j}, c_{i j}\right)\right] /\left[T E_{i}\left(y_{i}, x_{i j}\right)\right]
$$

\subsubsection{Pure technical efficiency (PTE)}

Pure technical efficiency $\left(\mathrm{PTE}=\theta_{2}\right)$ measures the increase in outputs that a farm could achieve if it were to use variable returns to scale (VRS) technology. According to the definition of Banker, et al. [5], $\theta_{1}$ and $\theta_{2}$ represent the proportional decrease in input that can be achieved by the farm to produce the given output under CRS and VRS assumptions, respectively. The same model (1) and data for inputs and output variables were used to calculate the VRS model.

\subsubsection{Scale efficiency (SE)}

Scale efficiency (SE) can be calculated from the difference between the $\mathrm{TE}_{\mathrm{VRS}}$ score and the $\mathrm{TE}_{\mathrm{CRS}}$ score. Using the relationship between $\mathrm{TE}_{\mathrm{VRS}}$ and $\mathrm{TE}_{\mathrm{CRS}}$ above, the scale efficiency measure for a farm (see Favero \& Papi [22] ; Johnes [25] ; Bjurek, et al. [8]) is computed as :

$$
S E_{i}\left(y_{i}, x_{i j},\right)=T E_{C R S}\left(y_{i}, x_{i j},\right) / T E_{V R S}\left(y_{i}, x_{i j},\right)
$$

where $S E_{i}=1\left(T E_{C R S}=T E_{V R S}\right)$ indicates scale efficiency that is operating at a point of CRS. A value $S E_{i}<1$, indicates the two technologies (CRS and VRS) do not coincide, or scale inefficiency. However, scale inefficiency can be due to the existence of either increasing or decreasing returns to scale. Then the next it can be resolved by running an additional DEA problem with non-increasing returns to scale (NIRS) imposed as suggested by Coelli, et al. [15].

\subsubsection{Farm-specific factors affecting analysis}

The second part of the methodology involved the specification and estimation of farm specific parameters in a Tobit model (5). Previous studies (see Haji [23] ; Speelman, et al. 
[34] ; Wadud [38]) commonly used this method to identify relationships between efficiency and suspected factors affecting efficiency. To evaluate the role of farm-specific efficiencies, the Tobit model (5) was run using SHAZAM econometrics software, special version 10 computer program (see Diana, et al. [19]).

$$
E_{i}=\beta_{0}+\beta_{1} z_{i 1}+\beta_{2} z_{i 2}+\beta_{3} z_{i 3}+\beta_{4} z_{i 4}+\beta_{5} z_{i 5}+\beta_{6} z_{i 6}+\beta_{7} z_{i 7}+\beta_{8} z_{i 8}+\varepsilon_{i}
$$

where $E_{i}=$ score of all efficiencies (TE, EE, $A E, P T E$ and $S E$, measured between 0 and 1) used separately as a dependent variable ; $\beta_{i}=$ parameters to be estimated ; $z_{i}=$ various farmspecific variables; and $\varepsilon_{i}=$ the residual error term that is independently and normally distributed. In this model we assumed that $\varepsilon_{i}$ distributed as $N\left(0, \sigma^{2}\right)$, where $\sigma^{2}$ is an unknown covariance matrix. The determinants of efficiency were modeled as a function of farm-specific human, physical and structural variables used as an independent variable : age of head of family (years) ; education (school years of household head) ; experience (cropping years) ; training (dummy variable, where 1 represents a farmer who is a trainee and 0 for otherwise) ; family size (number) ; off-farm income (dummy variable, where 1 represents a farmer who earns an off-farm income and 0 for otherwise); access to credit (dummy variable, where 1 represents access and 0 for otherwise) ; and women participation ${ }^{1}$ (dummy variable, where 1 represents participation by women and 0 for otherwise).

\section{Results and discussion}

The history of cultivation is long, although the farmers have only been cultivating on a commercial scale for 18 years. The variation in input costs and output was considerably large ; for example, the area of land used for cardamom ranged from 0.1 to 1.25 hectares, with an average of 0.40 hectares. Similarly, the range of output of cardamom yield lay in the range of 104 to $600 \mathrm{~kg} / \mathrm{ha}$. Labor represented the highest cost in cardamom production compared the other four inputs (Table 1). The range of gross income from cardamom was Rs. $20.8 \mathrm{~K} /$ ha to Rs. $120 \mathrm{~K} /$ ha with in average Rs. $84.4 \mathrm{~K} /$ ha. The farmers were get their market price range from Rs. $190 / \mathrm{kg}$ to Rs. $220 / \mathrm{kg}$ of cardamom output across the farms.

The socio-economic variables are also summarized in Table 1 . The education variable showed that $65 \%$ of farmers had a primary level of education, whereas $6 \%$ had never enrolled in school. The off-farm income was $20 \%$; the average age of farmer is 50 years ; approximately very low (37\%) had access to credit because of not enough land for collateral and high interest rate; and only 40\% have had training, low educational level and lack of job opportunities in the proximity of the farm.

\subsection{Efficiencies prediction}

The summary statistic of all efficiencies is presented in Table 2 and distribution of efficiencies provided in Figure 2. The mean level of overall TE was $90 \%$ and the indices ranged from $68 \%$ to $100 \%$ for the farms in the sample. This means in principle that farmers can potentially reduce their input by $10 \%$ in average and still they can achieve the same level of output from existing technology. The mean value of TE in this study was higher than the

\footnotetext{
${ }^{1}$ Women activity in cardamom farm was found such as, planting, weeding, husking and harvesting.
} 
Table 1. Descriptive statistics of input, output and cost used in efficiency analysis

\begin{tabular}{|c|c|c|c|c|}
\hline Description & Mean & St.d & Min & Max \\
\hline Land use of cardamom farm (ha/farmer) $\mathrm{x}_{1}$ & 0.40 & 0.21 & 0.10 & 1.25 \\
\hline Labor (total days/farmer) $\mathrm{x}_{2}$ & 14.60 & 6.24 & 5.00 & 30.00 \\
\hline Fertilizer $(\mathrm{kg} /$ farmer $) \mathrm{x}_{3}$ & 658.20 & 415.77 & 100.00 & $2,200.00$ \\
\hline Sapling (number/farmer) $\mathrm{x}_{4}$ & 362.10 & 249.26 & 25.00 & $1,200.00$ \\
\hline Fire wood (kg/farmer) $\mathrm{x}_{5}$ & 188.40 & 131.53 & 18.50 & 760.00 \\
\hline Production (kg/farmer) $y_{i}$ & 168.00 & 83.47 & 37.00 & 400.00 \\
\hline Yield $(\mathrm{kg} / \mathrm{ha})$ & 422.00 & 71.33 & 104.00 & 600.00 \\
\hline Total cultivated land (ha) & 1.80 & 1.02 & 0.25 & 4.30 \\
\hline \multicolumn{5}{|l|}{ Cost of inputs } \\
\hline Land tax $(\mathrm{Rs} /$ farmer $) \mathrm{c}_{1}$ & 8.17 & 4.40 & 2.00 & 25.00 \\
\hline Labor (Rs/farmer) $c_{2}$ & $1,174.6$ & 498.40 & 400.00 & $2,400.00$ \\
\hline Fertilizer (Rs/farmer) $c_{3}$ & 362.60 & 267.90 & 60.00 & $1,900.00$ \\
\hline Sapling (Rs/farmer) $\mathrm{c}_{4}$ & 362.00 & 249.00 & 25.00 & $1,200.00$ \\
\hline Fire wood (Rs/farmer) $c_{5}$ & 188.40 & 131.50 & 18.50 & 760.00 \\
\hline Gross income, in 1,000 (Rs/ha) & 84.42 & 14.26 & 20.80 & 120.00 \\
\hline \multicolumn{5}{|l|}{ Socioeconomics factors used in Tobit model } \\
\hline Age of head (years) $z_{1}$ & 50 & 14 & 24 & 94 \\
\hline Education (years) $z_{2}$ & 9 & 3.5 & 0 & 15 \\
\hline Family size (number) $z_{3}$ & 5 & 1.9 & 2 & 14 \\
\hline Cropping year (years) $z_{4}$ & 12 & 2.5 & 5 & 18 \\
\hline Dummy variables & Dummy $=1$ & Dummy $=0$ & & \\
\hline Female activity in cardamom farm $(\mathrm{HH}) z_{5}$ & 77 & 23 & & \\
\hline Access to credit $z_{6}$ & 37 & 63 & & \\
\hline Off-farm activity $z_{7}$ & 20 & 80 & & \\
\hline Training $z_{8}$ & 40 & 60 & & \\
\hline
\end{tabular}

Note: all are measured in Nepalese Rupee (RS), HHs=households, SPSS version 16.0 for window.

US\$1=Rs. 75 ; JP Yen $10=$ Rs. 8.5 in December, 2008 (Source : Nepal Rastra Bank)

main value of efficiency per study on average (0.74) of less developed countries, as reported by Bravo-Ureta, et al. [10].

The mean $\mathrm{AE}$ of the samples in the study area was found $58 \%$, from the range of $20 \%$ to $92 \%$. The combined effect of technical and allocative factors showed that the average EE level was $52 \%$, from the range of $18 \%$ to $92 \%$. This indicates the existence of substantial allocative and economic inefficiencies of cardamom farm in the study area. This means that the farmers were employing incorrect inputs given the input prices, so that on average, costs were $42 \%$ higher than on the cost-minimizing level. In other words, low level of EE scores suggest that there is still some scope to reduce in the cost of cardamom output without decreasing output given the existing technology. Thus, farmers could reduce the cost of production by $48 \%$ and still produce the same level of output.

The results from both the CRS and VRS versions of the DEA model showed that the score of TE among farmers was not significantly different. This shows that the SE score 
Table 2. Descriptive statistics of the efficiency in percent $(n=100)$

\begin{tabular}{|l|c|c|c|c|c|}
\hline \multicolumn{1}{|c|}{ Efficiencies } & Mean & St.d & Min & Max & Full efficient \\
\hline Pure Technical Efficiency (PTE) & 93 & 7 & 68 & 100 & 33 \\
\hline Technical Efficiency (TE) & 90 & 7 & 66 & 100 & 19 \\
\hline Economic Efficiency (EE) & 52 & 20 & 18 & 92 & 0 \\
\hline Scale Efficiency (SE) & 96 & 3 & 71 & 100 & 23 \\
\hline Allocative Efficiency (AE) & 58 & 20 & 20 & 92 & 0 \\
\hline
\end{tabular}

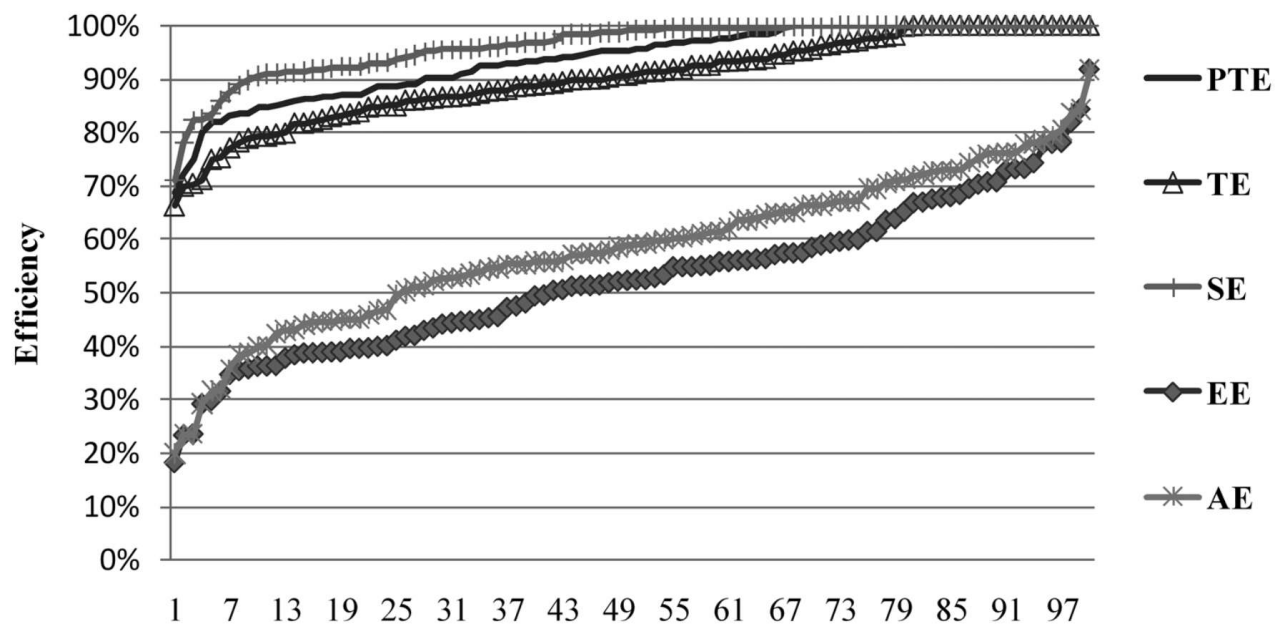

Cumulative frequency of farms

Figure 2. Distribution of various measures of efficiency (PTE, TE, EE, SE and AE).

was about 1 (average of 0.96 ) for each farmer. This result implies that very low level of scale inefficiency does exist in the study area. The result falls between those of studies by Haji [23], who found 1 (100\%) SE of vegetable farms, and Coelli, et al. [15] who reported an average of $94 \%$ for modern Boro rice production.

Mean SE of the sample cardamom farms was $96 \%$. Characteristics of optimal (CRS) and sub-optimal (IRS) and supra-optimal (DRS) farms are provided in Table 3. Of the 100 cardamom farms, $23 \%$ showed constant returns to scale (CRS), $24 \%$ farms operating below their optimal scale. This means that these farms could increase their technical efficiency by continuing to increase their current size of production more efficiently. The result also indicated that the $53 \%$ of the farms are showed above their optimal scale and hence could increase their technical efficiency by reducing their size. The scale efficiency results only reflect the cardamom farms in the sample. Furthermore, the source of scale inefficiency and their corresponding land used as an input and output of cardamom were also determined.

Figure 2 provides graphical representations of the cumulative efficiency distributions for the different efficiency measures. The frequency distributions for the different efficiency measures of the farms about $98 \%$ of the farms achieved more than $70 \%$ TE. In contrast, $78 \%, 99 \%, 88 \%$ and $100 \%$ of farms had scores of more than $70 \%$ for AE, PTE, EE and SE, 
Table 3. Descriptive statistics of total cultivated land, output by returns to scale (RTS)

\begin{tabular}{|c|c|c|c|c|c|c|c|}
\hline \multirow{2}{*}{ RTS } & & \multicolumn{3}{|c|}{ Total cultivated land (ha) } & \multicolumn{3}{c|}{ Cardamom output (kg/ha) } \\
\cline { 2 - 8 } & No. farms & Mean & Min & Max & Mean & Min & Max \\
\hline CRS & 23 & 1.27 & 0.40 & 2.50 & 432 & 104 & 600 \\
\hline IRS & 24 & 1.43 & 0.20 & 4.00 & 418 & 258 & 560 \\
\hline DRS & 53 & 2.22 & 0.40 & 4.30 & 419 & 320 & 520 \\
\hline
\end{tabular}

Source: Field survey, 2008

CRS, constant returns to scale, IRS, increasing returns to scale and DRS, decreasing returns to scale.

respectively. This shows the potential for increasing the productivity of farms in the study area. It was clear that many farmers were highly economically inefficient or underestimated the cost of inputs, which did not reflect their use of inputs or the overall technical efficiency. If those farmers improve their input and cost used efficiency, their farming activities might become sustainable and economically viable.

\subsection{Parameter estimation}

The second stage Tobit regressions explained some of the variations. The efficiency scores were regressed on the farm-level characteristics, since the efficiencies varied from zero to 1 . In general, the variables included in equation 5 are those usually incorporated in analyses of this type (see Belbase and Grabowski [7] ; Speelman, et al. [34]). Five separate

Table 4. Tobit regression coefficients of all efficiencies (TE, EE, AE, PTE and SE)

\begin{tabular}{|c|c|c|c|c|c|}
\hline \multirow{2}{*}{$\begin{array}{l}\text { Explanatory } \\
\text { variables }\end{array}$} & \multicolumn{5}{|c|}{ Coefficients } \\
\hline & TE & $\mathrm{EE}$ & $\mathrm{AE}$ & PTE & $\mathrm{SE}$ \\
\hline Constant & $1.58(2.26)^{* *}$ & $0.29(0.42)$ & $0.89(1.29)$ & $2.33(3.28)^{* * *}$ & $2.20(3.11)^{* * *}$ \\
\hline Age $\left(z_{i 1}\right)$ & $-0.44(-1.76)^{*}$ & $-0.44(-1.75)^{*}$ & $-1.73(-1.73)^{*}$ & $-0.48(-1.89)^{*}$ & $-0.47(-1.88)^{* *}$ \\
\hline Family size $\left(z_{\mathrm{i} 2}\right)$ & $0.59(1.02)$ & $0.42(0.74)$ & $0.43(0.74)$ & $0.22(0.40)$ & $0.75(1.31)$ \\
\hline Education $\left(z_{\mathrm{i} 3}\right)$ & $0.41(1.34)$ & $0.84(0.26)$ & $-0.28(-0.90)$ & $0.21(0.68)$ & $0.14(0.47)$ \\
\hline Experience $\left(z_{14}\right)$ & $0.62(2.10)^{* *}$ & $0.65(2.19)^{* *}$ & $0.62(2.12)^{* *}$ & $0.64(2.18)^{* *}$ & $0.64(2.17)^{* *}$ \\
\hline Training $\left(z_{\mathrm{i} 5}\right)$ & $0.61(2.74)^{* * *}$ & $0.37(1.73)^{*}$ & $0.35(1.64)^{*}$ & $0.64(2.93)^{* * *}$ & $0.50(2.30)^{* *}$ \\
\hline $\begin{array}{l}\text { Women } \\
\text { participation }\left(z_{16}\right)\end{array}$ & $1.50(6.58)^{* * *}$ & $1.49(6.55)^{* * *}$ & $1.52(6.65)^{* * *}$ & $1.48(6.50)^{* * *}$ & $1.49(6.55)^{* * *}$ \\
\hline Off-farm $\left(z_{\mathrm{i} 7}\right)$ & $1.04(4.28)^{* * *}$ & $1.13(4.60)^{* * *}$ & $1.17(4.74)^{* * *}$ & $1.19(4.49)^{* * *}$ & $1.14(4.66)^{* * *}$ \\
\hline $\begin{array}{l}\text { Access to credit } \\
\left(z_{i 8}\right)\end{array}$ & $0.89(4.23)^{* * *}$ & $0.90(4.34)^{* * *}$ & $0.94(4.51)^{* * *}$ & $0.94(4.49)^{* * *}$ & $1.04(4.93)^{* * *}$ \\
\hline $\begin{array}{l}\text { Standard error of } \\
\text { the estimate }(\sigma)\end{array}$ & 0.23 & 0.25 & 0.24 & 0.23 & 0.23 \\
\hline Variance $\left(\sigma^{2}\right)$ & 0.57 & 0.62 & 0.61 & 0.53 & 0.53 \\
\hline $\begin{array}{l}\text { Log of likelihood } \\
\text { function }\end{array}$ & 0.81 & -3.52 & -2.29 & 4.64 & 3.98 \\
\hline McFadden' $\mathrm{R}^{2}$ & 0.75 & 0.91 & 0.82 & 0.84 & 0.90 \\
\hline
\end{tabular}

Note: ${ }^{* * * * *}$ and $*$ indicates $1 \%, 5 \%$ and $10 \%$ level of significance respectively. Figures in parenthesis are $t$ values.

Note: Dependent variable: TE, EE, AE, PTE and SE, $\beta$ represent Coefficients Beta.

Note: $\mathrm{R}^{2}=1-(\mathrm{Log}$ of likehood function with respect to the parameters/Log of likehood function) 
Tobit coefficients are presented in Table 4.

Based on the results of the Tobit model, the parameter estimation showed that factors such as, farming experiences, credit access, women participation, training, as well as offfarm activities had a positive and statistically significant and influenced on all efficiency measures. Other variables were not significant ; education was positively but insignificantly related to TE, EE, PTE and SE. This result was consistent with results from the studies of Haji [23], Speelman, et al. [34] and Coelli, et al. [15].

The coefficient of farmer's age variable showed a negative and significant effect on TE, $\mathrm{EE}, \mathrm{AE}$ and PTE at the $10 \%$ significance level and on SE at the $5 \%$ significance level. This indicated that the younger farmers were more efficient because older farmers were not able to change or to adopt a new technology, and did not have the same level of physical strength for work. This finding supports the results of Battese and Coelli [6], Bozoğlu and Ceyhan [9] and Idiong [24], but contrasts to those of Dhungana, et al. [18]. The positive but insignificant impact of family size on all efficiency measures. This indicated that the cardamom farmers had a large family size (on average 5 per household). It is expected that large family size represent a large number of availability of labor, which may help to enhance the efficiency (see Nwaru [28]). Some studies have suggested that a large family size on a small land size may cause over-utilization (see Okike [36]). However, in this study, family size was not significant, possibly because numbers of dependent populations are relatively higher rather than economically active populations.

The positive and highly significant relationship between access to credit and efficiency suggested that farmers who face credit constraint on purchased inputs experience higher technical inefficiency. Farmers' access to credit from government or other sources enhances their timely acquisition of production inputs, which would enhance the productivity via efficiency. This result was consistent with the findings of Abdulai \& Eberlin [1], a negative and significant relationship between access to credit and inefficiency of maize and bean production in Nicaragua. Similarly, a positive effect of access to credit was found in studies on rice farms Kebede [26] and vegetable farms in Turkey (see Bozoğlu \& Ceyhan [9]).

The positive and significant effect of experience implied that cardamom farming leads to better managerial skills being acquired over time (Table 4). This means that cardamom farming is highly dependent on the experience of the farmers, particularly in this region. The findings are consistent with earlier studies by Kebede [26] and Dhungana, et al. [18]. On the other hand, the coefficient of education had the expected positive effect but this was not significant. This means being an educated farmer is not enough to cause significantly higher levels of efficiency, if it does not accompany a rearrangement of inputs to obtain higher output levels with a given technology. The findings of Coelli, et al. [15] showed that education had no significant effect, where it is below an average of four years of education. In comparison, Dhungana, et al. [18] reported a positive and significant effect of a slightly higher educational level. The current research did not reveal a significant effect even though average educational level was higher (9 years) than in other studies. However, this finding was consistent with those of Haji [23]. With respect to women's participation, the positive and highly significant coefficient supported the hypothesis that cardamom farms with a high level of participation by women are highly efficient (Table 4). This result, hence, 
suggested that the women work in farm with full devotion and play significant role on making farm more efficient compared to the male counterpart. This result was also consistent with the findings of Dhungana, et al. [18].

\section{Conclusions and recommendations}

Large cardamom based agroforestry system is generally referred as high value low volume crop as this demand less input including manure is low cost to compare the other food crops. This research work derived the efficiency indices for large cardamom in the Eastern hilly region of Ilam District of Nepal by using DEA model. The efficiency analysis revealed that few cardamom farmers were found efficient, however, majority farmers are still inefficient indicating that there could be substantial decreases in inputs and still can produce the same level of output, had they maintained the existing technology on cardamom farms. Thus, the results of this research will be useful in identifying the efficient farmers to use on benchmarking for setting targets and finding weaknesses in the current technology. In addition, inefficient (relatively efficient) farmers can also improve their efficiency further through learning the good allocation decisions from efficient farmers. Hence, the DEA model inspires the best agricultural performance by using the benchmarking.

The results from Tobit model provided the evidence how input could be used and minimize the costs to enhance the efficiency under the existing technologies. Based on the comparative efficiency analysis, efficient farmers' profile was indicated that they have higher access to credit, participated in training, higher level of women's participation, farming experiences and are younger compared to inefficient farmers. Similarly, smaller family having off-farm incomes were observed more efficient than larger family without off-farm income.

From policy point of view, this analysis identification of those factors contributing to efficiency differentials among the cardamom growing farmers might help to make better policy for intervention. Based on these results, authors propose to increase the efficiency and make the strategies to focus on more qualified and market oriented training for famers, integrating women into the training, additional income sources that could be used for farm activities and access to credit with low interest and in time would be better for them to prosper. Establishing the strategies is a difficult task for policy makers that needed additional efforts on investment in infrastructure.

Finally, this empirical study did not include certain variables that may have important role on explaining productivity and inefficiency effects, such as the factors of extension, rainfall data, marketing, general policies and profit efficiency. These factors will be explored in future studies for a more refined analysis of the topic. Inefficiency is not just a result of the aforementioned factors. For significant changes to policy, further research is critical to develop production strategies and models that incorporate all relevant inefficiency effects.

\section{Acknowledgement}

Authors are grateful to two anonymous referees worthy comments on the paper. We would like to thanks Kubota fund for providing the research grant and thanks Yoneyama 
Rotary club for their financial support to carry out this research work.

\section{References}

[1] Abdulai, A., and Eberlin, R., "Technical efficiency during economic reform in Nicaragua: evidence from farm household survey data, Economic Systems," vol. 25, 2001, pp. 113-125.

[2] Agriculture Perspective Plan (APP), Agricultural Project Service Center and John Mellor Associates, Inc. NPC/HMGN and ADB, Kathmandu, Nepal, 1995.

[3] Agro Enterprise Centre (AEC), Federation of Nepalese Chambers of Commerce and Industry, Teku, Kathmandu, Nepal, 2006. Available <http://www.agripricenepal.com $>$.

[4] Alene, A.D., Manyong, V.M., and Gockowski, J., "The production efficiency of intercropping annual and perennial crops in southern Ethiopia: a comparison of distance functions and production frontiers," Agricultural Systems, vol. 91(1), 2006, pp. 251-270.

[ 5 ] Banker, R.D., Charnes, A., and Cooper, W.W., "Models for the estimation of technical and scale inefficiencies in DEA," Management Science, vol. 30, 1984, pp. 1078-1092.

[6] Battese, G., and Coelli, T., "A model for technical inefficiency effects in a stochastic frontier production function for panel data," Empirical Economics, vol. 20, 1995, pp. 325-332.

[7] Belbase, K., and Grabowski, R., "Technical efficiency in Nepalese agriculture," Journal of Development Areas, vol. 19, 1985, pp. 515-525.

[ 8 ] Bjurek, H.L., Hjalmarsson, L., and Forsund, F.R., "Deterministic parametric and non-parametric estimation in service production," Journal of Economics, vol.10, 1990, pp. 27-37.

[ 9 ] Bozoğlu, M., and Ceyhan, V., "Measuring the technical efficiency and exploring the inefficiency determinants of vegetable farms in Samsun province, Turkey," Agricultural Systems, vol. 94, 2007, pp. 649-656.

[10] Bravo-Ureta, B.E., Solis, D., Moreira Lopez, V.H., Maripani, J.F., Thaim, A., and Rivas, T., "Technical efficiency in farming: A meta regressing analysis," Journal of Productivity Analysis, vol. 27, 2007, pp. 57-72.

[11] Central Bureau of Statistics (CBS), Preliminary Projection National Account FY 2007/2008, National Planning Commission Secretariat, Government of Nepal, 2007.

[12] Charnes, A., Cooper, W.W., and Rhodes, E., "Measuring the efficiency of decision making units," European Journal of Operational Research, vol. 2, 1978, pp. 429-444.

[13] Chavas, J., and Cox, T.L., "A non-parametric analysis of agricultural technology," American Journal of Agricultural Economics, vol. 70, 1988, pp. 303-310.

[14] Chavas, J., Petrie, R., and Roth, M., "Farm household production efficiency: evidence from Gambia," American Journal of Agricultural Economics, vol. 87, 2005, pp. 160-179.

[15] Coelli, T., Rahman, S., and Thirtle, C., "Technical, allocative, cost and scale efficiencies in Bangladesh rice cultivation: a non-parametric approach," Journal of Agricultural Economics, vol. 53(3), 2002, pp. 607-627.

[16] Coelli, T.J., and Perelman, S., "A comparison of parametric and non-parametric distance functions: with application to European railways," European Journal of Operational Research, vol. 117, 1999, pp. 326-339.

[17] Dhungana, B., Sugimoto, Y., Yamamoto, N., Kirimura, M., and Nishiwaki, A., "Technical efficiency measurement and estimation of the efficiency determinants of citrus and cereal mix-farms in mid-hill, Nepal: a DEA approach," The Japanese Journal of Rural Economics, Special Issue, 2009, pp. 567-574.

[18] Dhungana, B.R., Nuthall, P.L., and Nartea, G.V., "Measuring the economic inefficiency of Nepalese rice farms using Data Envelopment Analysis," Australian Journal of Agricultural and Resource Economics, vol. 48, 2004, pp. 347-369.

[19] Diana, W., Kenneth, J., and White, D.B., SHAZM, Econometrics software version 10. Northwest Econometrics, Ltd. Vancouver, B.C., Canada, 2007.

[20] Fare, R., Grosskopf, S., and Lovell, C.A.K., Production Frontier, Cambridge University Press, 
Cambridge, 1994.

[21] Farrell, M.J., "The measurement of productive efficiency," Journal of the Royal Statistical Society, vol. 120, 1957, pp. 253-281.

[22] Favero, C.A., and Papi, L., "Technical efficiency and scale efficiency in the Italian Banking sector : a non-parametric approach," Applied Economics, vol. 27, 1995, pp. 385-395.

[23] Haji, J., "Production efficiency of smallholders vegetable-dominated mixed farming systems in Eastern Ethiopia : a non-parametric approach,” Journal of African Economics, vol. 6(1), 2006, pp. $1-17$.

[24] Idiong, I.C., "Estimation of farm level technical efficiency in small-scale swamp rice production in Cross River Site of Nigeria: a stochastic frontier approach," World Journal of Agricultural Sciences, vol. 3(5), 2007, pp. 653-658.

[25] Johnes, G., "Scale and technical efficiency in the production of economic of economic research," Applied Economic Letters, vol. 2, 1995, pp. 7-11.

[26] Kebede, T.A., Farm household technical efficiency : a stochastic frontier analysis, A study of rice producers in Mardi-Watershed in the western development region of Nepal, Master Thesis, Department of Economic and Social Science, Agricultural University of Norway.

[27] Ministry of Agriculture \& Cooperatives, Agri-Business Promotion and Ministry of Finance, MOF, 2007, Economy survey FY 2006/07, His Majesty of Government of Nepal, 2007. Available from : <http://www.mof.gov.np/publication/budget/pdf/2000/ch5.pdf>.

[28] Nwaru, J.C., Rural credit market and resource use in arable crop production in Imo state of Nigeria, PhD Thesis, Michael Okpara University of Agriculture, Umudike, 2004.

[29] Okike, I., Crop livestock interaction and economic efficiency of farmers in the Savannah Zone of Nigeria, Unpublished PhD Thesis, Department of Agricultural Economics, University of Ibadan, 2000.

[30] Picazo-Tadeo, A.J., and Reig-Martinez, E., "Outsourcing and efficiency: the case of Spanish citrus farming," The Journal of the International Association of Agricultural Economists, vol. 35(2), 2007, pp. 213-222.

[31] Rao, V.G., Mande, S., and Kishore, V.V.N., "Study of drying characteristics of large cardamom," Biomass and Bio-energy, vol. 20(1), 2001, pp. 37-43.

[32] Rios, A.R. and Shively, G.E., Farm size and non-parametric efficiency measurements for coffee farms in Vietnam, Paper presented at American Agricultural Economics Association annual meeting, Providence, Rhode Island, July 24-27, 2005.

[33] Sharma, E., and Ambasht, R.S., "Biomass, productivity and energy in Himalayan alder plantations,” Ann. of Bot., vol.67, 1991, pp. 285-293.

[34] Sharma, K.R., Leung, P., and Zealeski, H.M., "Technical, allocative and economic efficiencies in swine production in Hawaii : a comparison of parametric and nonparametric approaches," Agricultural Economics, vol. 20, 1999, pp. 23-35.

[35] Sharma, R., Sharma, G., and Sharma, E., "Energy efficiency of large cardamom grown under Himalayan alder and natural forest," Journal of Agroforestry Systems, vol. 56, 2002, pp. 233-239.

[36] Speelman, S., Marijke, D., Buysse, J., and D’Haese, L., "A measure for the efficiency of water use and its determinants: a case study of small-scale irrigation schemes in North-West Province, South Africa," Agricultural Systems, vol. 98, 2008, pp. 31-39.

[37] Waded, A., and White, B., "Farm household efficiency in Bangladesh, a comparison of stochastic frontier and DEA methods," Applied Economics, vol. 32, 2000, pp. 1665-1673.

[38] Wadud, A., "Technical, allocative and economic efficiency of farms in Bangladesh : a stochastic frontier and DEA approach," Journal of Developing Areas, vol. 37(1), 2003, pp. 109-126.

[39] Zhu, J., DEA Excel solver software for computing DEA models, 2002.

[40] Zomer, R. and Menke, J., "Site index and biomass productivity estimates for Himalayan alderlarge cardamom plantation, a model agroforestry system of the eastern mid-hill of Nepal," Mountain Research and Development, vol. 13, 1993, pp. 235-255. 